\title{
Effect of different exposure compounds on urinary kinetics of aluminium and fluoride in industrially exposed workers
}

\author{
F Pierre, F Baruthio, F Diebold, P Biette
}

\begin{abstract}
Objective-To conduct a field study to obtain information on the urinary concentrations of aluminium (Al) and fluoride $\left(F^{-}\right)$depending on the different compounds exposed to in the aluminium industry.

Methods-16 workers from one plant that produced aluminium fluoride $\left(\mathrm{AlF}_{3}\right)$, and from two plants that produced aluminium electrolytically by two different processes participated in the study for one working week. Pollutants were monitored by eight hour personal sampling every day, and urine samples were collected during the week. $A 1$ and $F^{-}$were analysed in both atmospheric and urine samples by atomic absorption spectrometry and an ion selective electrode.
\end{abstract}

Results-The principal results show different characteristics of kinetic curves of $A l$ and $\mathrm{F}^{-}$excretion in workers with different exposures. Some characteristics of excretory peaks were linked to specific exposures-for instance, after exposure to $\mathrm{AlF}_{3}$ there was one delayed $\mathrm{Al}$ peak associated with one delayed $F^{-}$peak about eight hours after the end of the daily shift, and after mixed exposure to $\mathrm{HF}$ and $\mathrm{AlF}_{3}$, two $F^{-}$peaks were noted, one fast peak at the end of the shift and another delayed peak at 10 hours synchronised with an $\mathrm{Al}$ peak. In one of the electrolysis plants, the exposure to $A l$ and $F^{-}$compounds led to the simultaneous excretion of $\mathrm{Al}$ and $\mathrm{F}$ peaks, either as a single peak or two individual ones depending on the type of technology used on site (open or enclosed potlines). The average estimated half life of $\mathrm{Al}$ was 7.5 hours, and of $\mathrm{F}^{-}$about nine hours. Quantitative relations between excretion and exposure showed an association between the $F^{-}$atmospheric limit value of $2.5 \mathrm{mg} / \mathrm{m}^{3}$ with a urinary $F^{-}$concentration of $6.4 \mathrm{mg} / \mathrm{g}$ creatinine at the end of the shift, a peak of $7.4 \mathrm{mg} / \mathrm{g}$ creatinine, and $7.4 \mathrm{mg}$ excreted a day. For $\mathrm{Al}$, the exposure to $1.36 \mathrm{mg} / \mathrm{m}^{3}$ during the shift corresponded to a urinary concentration at the end of the shift of $200 \mu \mathrm{g} / \mathrm{g}$ creatinine. Daily excretion of $200 \mu \mathrm{g}$ corresponded to an exposure to $0.28 \mathrm{mg} / \mathrm{m}^{3}$. Conclusion-Particular differences in the behaviour of $\mathrm{Al}$ and $\mathrm{F}^{-}$in urine depended upon the original molecular form in the pollutant. These results reinforce the principle that, in biological monitoring, the sampling strategy and the choice of limit value should be dependent on kinetic data that take the exposure compound of the element in question into account.

(Occup Environ Med 1995;52:396-403)

Keywords: aluminium; fluoride; biological monitoring

Aluminium (Al) is one of the most common elements and was long considered to be harmless. Recently, considerable toxic effects of aluminium have been found. Increasing research has been directed towards understanding diseases occurring in patients with impaired renal function on long term haemodialysis. ${ }^{1}$ It was recognised that the main pathology, dialytic encephalopathy, was caused by the use of solutions containing $\mathrm{Al}^{2}{ }^{23}$ Other studies examined its toxic effects on bone and mineral metabolism. ${ }^{4}$

Exposure to $\mathrm{Al}$, and metal compounds containing $\mathrm{Al}$ is common in metal and metal processing industries. Certain studies on the health of workers in the $\mathrm{Al}$ production industry have identified several adverse effects. Some of these are related to exposure to fluoride $\left(\mathrm{F}^{-}\right)$, but pulmonary diseases (fibrosis) ${ }^{5-8}$ and suspected neurological disorders ${ }^{9}{ }^{10}$ were also reported.

Occupational exposure to dusts containing $\mathrm{Al}$ can increase intake through the respiratory tract. In workers thus exposed, increased $\mathrm{Al}$ concentrations were found in serum and urine. ${ }^{11-16}$ Few studies have been carried out on the biological monitoring of workers exposed to Al. ${ }^{11-17}$ One reason for this is the difficulty inherent in the analysis of Al. Also, recent interest in the toxicology of $\mathrm{Al}$ has focused on $\mathrm{Al}$ soluble in water.

The biological monitoring of $\mathrm{F}^{-}$has been studied in greater depth. ${ }^{18-25}$

The purpose of our study was to investigate the relation between occupational exposure and the variations of $\mathrm{Al}$ and $\mathrm{F}^{-}$concentrations in the urine of exposed workers. The survey was conducted in the French aluminium industry among workers exposed to different $\mathrm{Al}$ compounds varying both chemically and in occupational exposure characteristics.

\section{Subjects and methods}

POPULATIONS AND OCCUPATIONAL EXPOSURES The study was carried out on 16 male workers exposed to $\mathrm{Al}$ compounds in two different industrial processes: 
(1) Production of aluminium fluoride $\left(\mathrm{AlF}_{3}\right)$ in plant $\mathrm{A}$ was with a dry process that used alumina $\left(\mathrm{Al}_{2} \mathrm{O}_{3}\right)$ and hydrofluoric acid $(\mathrm{HF})$. Two workers $\left(A_{1}\right.$ and $\left.A_{2}\right)$ were followed up. $A_{1}$ was 28 years old and had been mainly exposed to $\mathrm{AlF}_{3}$ dust for two months while working in the bagging section of the plant. $\mathrm{A}_{2}$ was 37 years old and had been exposed to $\mathrm{AlF}_{3}$, $\mathrm{HF}$, and $\mathrm{Al}_{2} \mathrm{O}_{3}$ for 14 years while involved in the production of $\mathrm{AlF}_{3}$. These two volunteers worked eight hours a day (500 am to $100 \mathrm{pm}$ ) for five days after two days rest.

(2) Electrolytic production of $\mathrm{Al}$ occurred in two selected plants (B and C), and the workers studied were located in the potroom where alumina is reduced to $\mathrm{Al}$ by electrolysis with cells connected in series called potlines. Prebaked anodes were used. Workers were exposed to a mixture of pollutants, mainly compounds with $\mathrm{Al}$ and $\mathrm{F}$ identified as: $\mathrm{NaAlF}_{4}, \mathrm{Na}_{2} \mathrm{AlF}_{5}, \mathrm{NaF}, \mathrm{Na}_{2} \mathrm{Al}_{2} \mathrm{~F}_{8}, \mathrm{HF}, \mathrm{Al}_{2} \mathrm{O}_{3}$, $\mathrm{AlF}_{3}$, and $\mathrm{Na}_{3} \mathrm{Al} \mathrm{F}$.

In plant $\mathrm{B}$, where potlines were enclosed and equipped with a pot fume collection, nine potroom workers were followed up. Five of them (aged 34, 41, 35, 32, and 35 years with exposure durations of $9,13,9,7$, and 20 years, respectively) worked an eight hour shift (5 $00 \mathrm{am}$ to $100 \mathrm{pm}$ ) for three days after two days rest. The four other workers (aged 45, 31,28 , and 46; durations of exposure $11,7,3$, and 19 years, respectively) worked a shift of eight hours ( $100 \mathrm{pm}$ to $900 \mathrm{pm}$ ) for three days after two days rest.

In plant $\mathrm{C}$, where the potlines were open, five workers in the potroom participated in the study (aged: 40, 57, 44, 49, and 46 years with exposures of $9,10,8,1$, and 14 years, respectively). They worked eight hours a day $(100 \mathrm{pm}$ to $900 \mathrm{pm}$ ) for four days after two days rest.

Each volunteer was informed of the purpose of the study and was supposed to be representative of $\mathrm{Al}$ exposure in each type of task. This was confirmed by the occupational physician and the technical staff of each plant.

The home tap water of each worker was analysed. In plant $\mathrm{A}$, the mean (range) $\mathrm{Al}$ content of the volunteers' home tap water was $54(10$ to 92$) \mu \mathrm{g} / 1$. The concentration of $\mathrm{Al}$ in the factory water was $34 \mu \mathrm{g} / \mathrm{l}$. In plant $\mathrm{B}, \mathrm{Al}$ concentrations of home tap water was 15 (6 to 20) $\mu \mathrm{g} / \mathrm{l}$. The concentration of $\mathrm{Al}$ in the plant water was $33 \mu \mathrm{g} / \mathrm{l}$. In plant $\mathrm{C}$, the concentration of $\mathrm{Al}$ in home tap water was 18 (9 to 22) $\mu \mathrm{g} / \mathrm{l}$ and in the $\mathrm{Al}$ plant was $17 \mu \mathrm{g} / \mathrm{l}$.

\section{AIR SAMPLES}

Airborne particulate sampling was performed on quartz microfibre filters (Whatman QM-A, diameter $37 \mathrm{~mm}$ ) in Millipore filter holders. The cassettes were clipped to the collar of the work clothes, near the breathing zone of the subjects. Sampling was continued for the entire duration of a shift, divided into two periods if possible when dust pollution was significant. Membrane filter pumps (Dupont model P2500) were used at a flow rate of $1 \mathrm{l} / \mathrm{min}$. The filter holders were in closed face configuration allowing the selective sampling of inspirable particles.
In the case of exposure to fluoride (in the production of $\mathrm{AlF}_{3}$ and in electrolytic production of $\mathrm{Al}$ ) both particulate and gaseous $\mathrm{F}^{-}$ compounds were collected with $37 \mathrm{~mm}$ closed face filter holders (Millipore) containing one DM800 metricel membrane (Gelman) for particles, and one $\mathrm{Na}_{2} \mathrm{CO}_{3}$ impregnated paper filter (Durieux) for gas.

ANALYSIS OF AIR SAMPLES

The reagents used for analysis of $\mathrm{Al}$ were $65 \%$ nitric acid (RP Normapur Prolabo), $40 \% \mathrm{HF}$ (Prolabo, Merck), and $\mathrm{Al}$ ( $1 \mathrm{~g} / 1$ titrisol (Merck)). The aluminium content of the samples was analysed by the method developed by the French National Research and Institut for Occupational Health (INRS) ${ }^{26} 27$ which takes into account particles deposited both on the filter and on the inner walls of the filter holder. The soluble fraction was obtained by dissolving the dusts in $10 \mathrm{ml}$ of distilled water inside the holder. After mechanical stirring for 30 minutes, the solution was filtered through the quartz fibre filter and diluted to $20 \mathrm{ml}$. To determine the insoluble fraction, $\mathrm{HF}(3 \mathrm{ml})$ and nitric acid $(2 \mathrm{ml})$ were added directly to the cassette to dissolve both filter and particles. The solution was then diluted to $20 \mathrm{ml}$. Both soluble and insoluble fractions of $\mathrm{Al}$ were evaluated with DCPOES (direct current plasma - optical emission spectrometry) with a Spectrametrics Spectraspan III B, at $396 \cdot 1 \mathrm{~nm}$. Standards were prepared from $\mathrm{Al}(1.0 \mathrm{~g} / \mathrm{l})$ titrisol grade solution (Merck). The matrices of the standards and the samples were matched.

For analysis of gaseous $\mathrm{F}^{-}$, the impregnated filter was leached with distilled water, an equivalent volume of total ionic strength adjustment buffer (TISAB/ORION) was added to the solution, and the $\mathrm{F}^{-}$concentration was measured with an Orion selective electrode (94-09). For analysis of particulate $\mathrm{F}^{-}$, the membrane was heated in an $\mathrm{Na}_{2} \mathrm{CO}_{3}$ mixture to dissolve the insoluble particles. After cooling, the mixture was dissolved in distilled water and the solution was filtered after precipitation of interfering ions. The $\mathrm{F}^{-}$ content of the solution was determined by the same method as used for gaseous $\mathrm{F}^{-}$.

\section{URINE SAMPLES}

For each subject, 24 hour urine was collected with generally six samples a day for four to seven days. Sample times were chosen to collect urine just before the shift, at midshift, and at the end of the shift. The other samples were taken at subjects' homes with an attempt to keep the sampling intervals as regularly spaced as possible. Collection started at home on the morning of the first day before work and was continued until after the last day of the two day rest period.

During the working day, samples were collected at the electrolysis plant and at the $\mathrm{AlF}_{3}$ production site only after the workers had taken a shower. In the third plant, sampling was performed in a clean room without work clothes and after hands had been washed.

Urine was collected in polyethylene bottles 
$(500 \mathrm{ml})$. Bottles, caps, and seals were carefully cleaned beforehand in acid and rinsed with distilled water. Collection time was noted, specific gravity, temperature, and volume were measured. One sample was preserved for the assessment of creatinine. Nitric acid was added to the sample used in the analysis of $\mathrm{Al}$ ( $65 \%$ Suprapure Merck equivalent to $1 \%$ of the sample volume) and the solution was stored at $-20^{\circ} \mathrm{C}$ until analysis.

ANALYSIS OF URINARY CREATININE

Creatinine concentration was measured by photometry (test, combination creatinine, Boehringer) on a Cobas-Bio analyser (Roche).

\section{ANALYSIS OF URINARY Al}

The main analytical difficulties in the measurement of $\mathrm{Al}$ concentrations were potential problems of contamination during urine sampling, transport, storage, and sample treatment. Sampling and sample preparation were therefore performed under strictly controlled conditions. Clean recepticals and tested reagents were used. Analytical procedures required a quality control scheme.

Urinary Al concentration was evaluated by electrothermal atomic absorption spectrometry with a Perkin Elmer 3030/Zeeman device, equipped with an HGA 600 furnace and an AS 60 autosampler. Analysis was performed with pyrolytic graphite tubes at $309.3 \mathrm{~nm}$ by a direct method derived from Oster. ${ }^{28}$

The urine sample was diluted (1/5) with an original diluent (Triton X $100(0.5 \%), \mathrm{HNO}_{3}$ $(0.02 \mathrm{M})$, and EDTA $(0.5 \%))$. Standard addition was used for calibration. The detection limit calculated (by the formula: mean blank value +3 SDs) with results from three months was $3 \cdot 8 \mu \mathrm{g} / 1$.

The between run coefficient of variation varied routinely by $4 \cdot 2 \%$ over three months at a concentration of $80 \mu \mathrm{g} / \mathrm{l}$. Quality control samples provided by Nycomed (Oslo, Norway batch 108) were included in each analytical series. The external quality control was performed by participating in the French interlaboratory quality control programme for aluminium in dialysis fluids. Urinary $\mathrm{Al}$ and $\mathrm{F}^{-}$concentrations were expressed per $\mathrm{g}$ creatinine. Only samples containing between 0.5 and $3.0 \mathrm{~g}$ creatinine/ 1 were taken into account for correction of urinary results.

\section{ANALYSIS OF URINARY $F$}

In the case of coexposure to $\mathrm{F}^{-}$compounds (gas or dust), the $\mathrm{F}^{-}$concentration was determined just after collection in fresh urine at room temperature by means of a selective ion electrode (Orion 94-09), with the analytical technique described by Tusl. ${ }^{29}$

The external quality control was assumed by participating to an international programme between laboratories (Centre de Toxicologie Québec).

\section{STATISTICAL ANALYSIS}

Version IV of the Statgraphics computer software package (Manugistics) was used for descriptive statistics and estimation of linear regression models.

Half lives of $\mathrm{Al}$ and $\mathrm{F}^{-}$in urine were estimated by graphic analysis of decreasing rates $v$ time. ${ }^{30}$

\section{Results}

To clarify the presentation and to avoid a loss of information, only individual kinetics curves are shown here.

EXPOSURE TO $\mathrm{AlF}_{3}$

Figure 1 shows the urinary $\mathrm{Al}$ and $\mathrm{F}^{-}$concentrations /g creatinine plotted against time (each point is located at the time when urine was sampled). It corresponds to a subject $\left(A_{1}\right)$
Figure 1 Atmospheric and urinary $A l$ and $F$ concentrations in worker $A_{1}$ (bagging worker in $\mathrm{AlF}_{3}$ production). Air concentrations of $A l$ and $F^{-}$correspond to the soluble part.

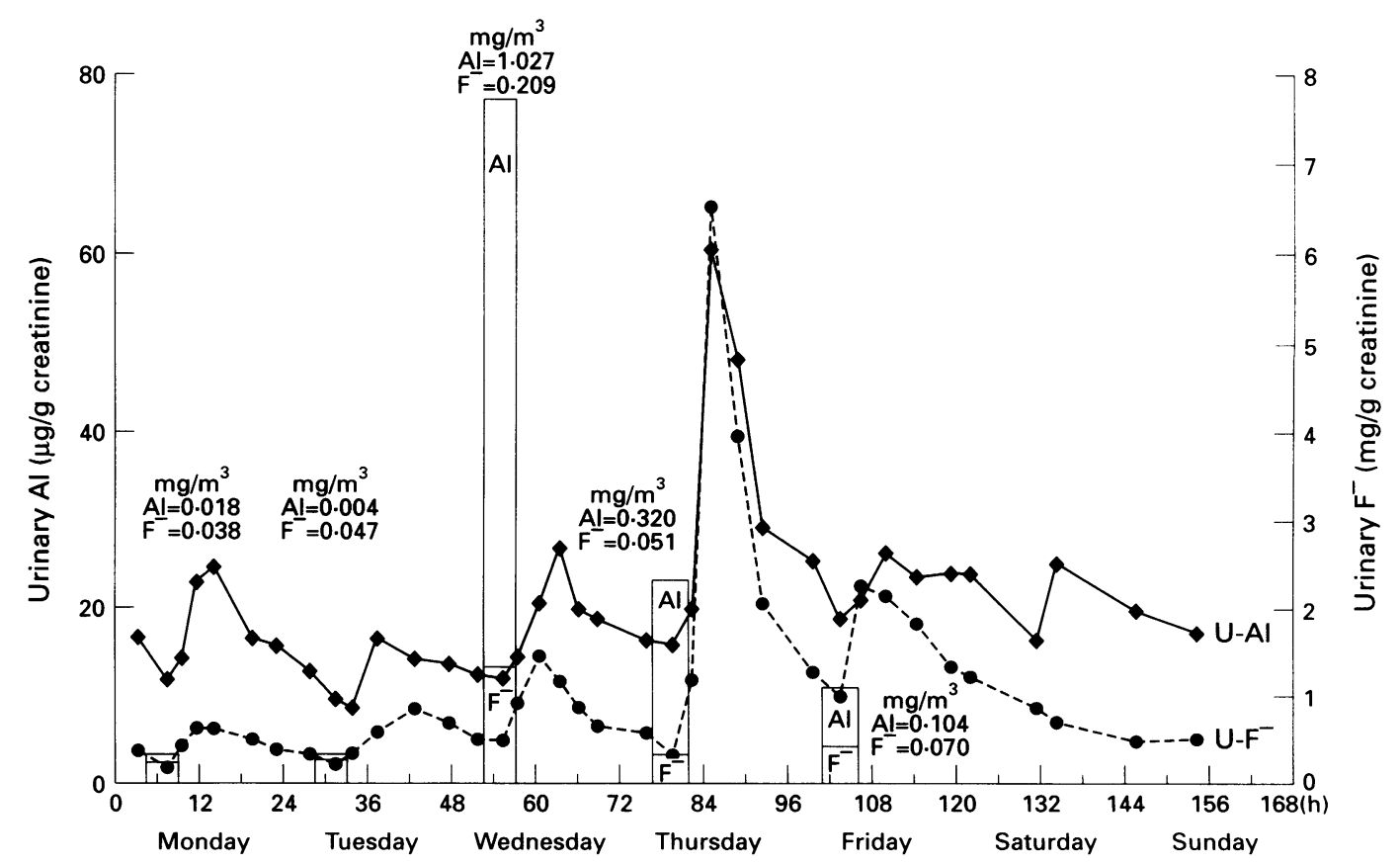


who regularly bagged $\mathrm{AlF}_{3}$ powder in the $\mathrm{AlF}_{3}$ production plant (A). The only modification of his task was the additional bagging of cryolite $\left(\mathrm{Na}_{3} \mathrm{AlF}_{6}\right)$ on the Thursday shift.

The urinary concentrations of $\mathrm{Al}$ from individual workers showed a daily rhythm: each day shift was followed by an increase in urinary $\mathrm{Al}$ excretion with maximal concentration at a regular interval after the end of exposure. The Thursday peak was higher, which seemed to be related to the exposure to cryolite.

It seems that the kinetics of urinary $\mathrm{F}^{-}$and Al were similar each day, with synchronisation of peaks. Surprisingly, the highest daily $\mathrm{F}^{-}$concentration was not at the end of the exposure time, as would be expected. This finding is even more surprising when one considers that the subject's workload was more intensive at the beginning of his shift. The effective end of the work (jobbing work) did not correspond to the official end of the shift.

The Thursday peaks with a shorter delay showed a relative difference in the $\mathrm{Al} / \mathrm{F}^{-}$ratio attributed to the handling of cryolite.

EXPOSURE TO HF AND AlF 3

In the case of simultaneous exposure to $\mathrm{HF}$ and $\mathrm{AlF}_{3}$ during production of $\mathrm{AlF}_{3}$ (subject $\mathrm{A}_{2}$ ) the $\mathrm{F}^{-}$curve had a double peak each day (fig 2). One started during the shift and peaked at the end of exposure, the other one peaked after a delay of about 10 hours. The second peak was narrower than the first, and was located on its decreasing slope. The corresponding results of each day's personal air samples are shown on the same graph. The pollution consisted of gaseous $\mathrm{HF}$, and particulate $\mathrm{AlF}_{3}$. The ratio between gaseous and particulate varied from day to day.

The urinary $\mathrm{Al}$ concentrations for Tuesday, Wednesday, Thursday, and Friday, showed a single peak at about the same time after the end of exposure as occurred in volunteer $A_{1}$ exposed to $\mathrm{AlF}_{3}$. It was found that the $\mathrm{Al}$ peak corresponded exactly to the second daily peak for $\mathrm{F}^{-}$.

The difference in the exposures between the two workers was the exposure to $\mathrm{HF}$ of volunteer $A_{2}$. It is possible that the first $F^{-}$ peak corresponded to the excretion of $\mathrm{F}^{-}$ coming from $\mathrm{HF}$ and the second one from $\mathrm{AlF}_{3}$. This result reinforced the hypothesis of a linkage between the exposure to particulate $\mathrm{F}^{-}$from $\mathrm{AlF}_{3}$ and the existence of a second $\mathrm{F}$ peak.

The volunteer $\mathrm{A}_{2}$ worked throughout the whole shift, unlike $A_{1}$ who accomplished his task rapidly in the first half of the shift. The delay between the end of the time of exposure and the end of the normal shift could be four hours. This delay could explain the different positions of the $\mathrm{Al}$ peaks in $\mathrm{A}_{2}$ and $\mathrm{A}_{1}$, which were different by one urine sample.

\section{EXPOSURE TO POTROOM POLLUTANTS}

Figure 3 shows the curves of urinary $\mathrm{Al}$ and $\mathrm{F}$ in the aluminium smelters of plant B and C.

In plant $B$, with enclosed potlines, nine workers were followed up. The curves of all nine workers show the same characteristics. Figure 3 shows the curves of two of these workers $\left(B_{1}\right.$ and $\left.B_{2}\right)$. They show a single $A l$ and $\mathrm{F}^{-}$peak daily, at about the time of the sample taken after the shift, or in the next sample. The position of these peaks close to the end of the daily exposure was not consistent with the previous results in several ways: both $\mathrm{Al}$ and $\mathrm{F}^{-}$curves were synchronous; their peaks were close to the end of the shift; the $\mathrm{Al}$ peaks were not positioned as in the case of exposure to $\mathrm{AlF}_{3}$ (figs 1 and 2); the $\mathrm{F}^{-}$peak seemed to correspond to that of exposure to HF.

In plant $\mathrm{C}$, with open potlines, urinary excretion of $\mathrm{Al}$ and $\mathrm{F}^{-}$seemed slightly different (fig 4, workers $\mathrm{C}_{1}$ and $\mathrm{C}_{2}$ ). It was possible to discriminate a broad peak for $\mathrm{Al}$ that corresponded to a broad peak for $\mathrm{F}^{-}$every day. The wide peak could have been the combination of
Figure 2 Atmospheric and urinary $A l$ and $F$ concentrations in worker $\mathrm{A}_{2}$ (in $\mathrm{Al} \mathrm{F} \mathrm{F}_{3}$ production). Air concentrations of $A l$ and $F^{-}$correspond to the soluble part.

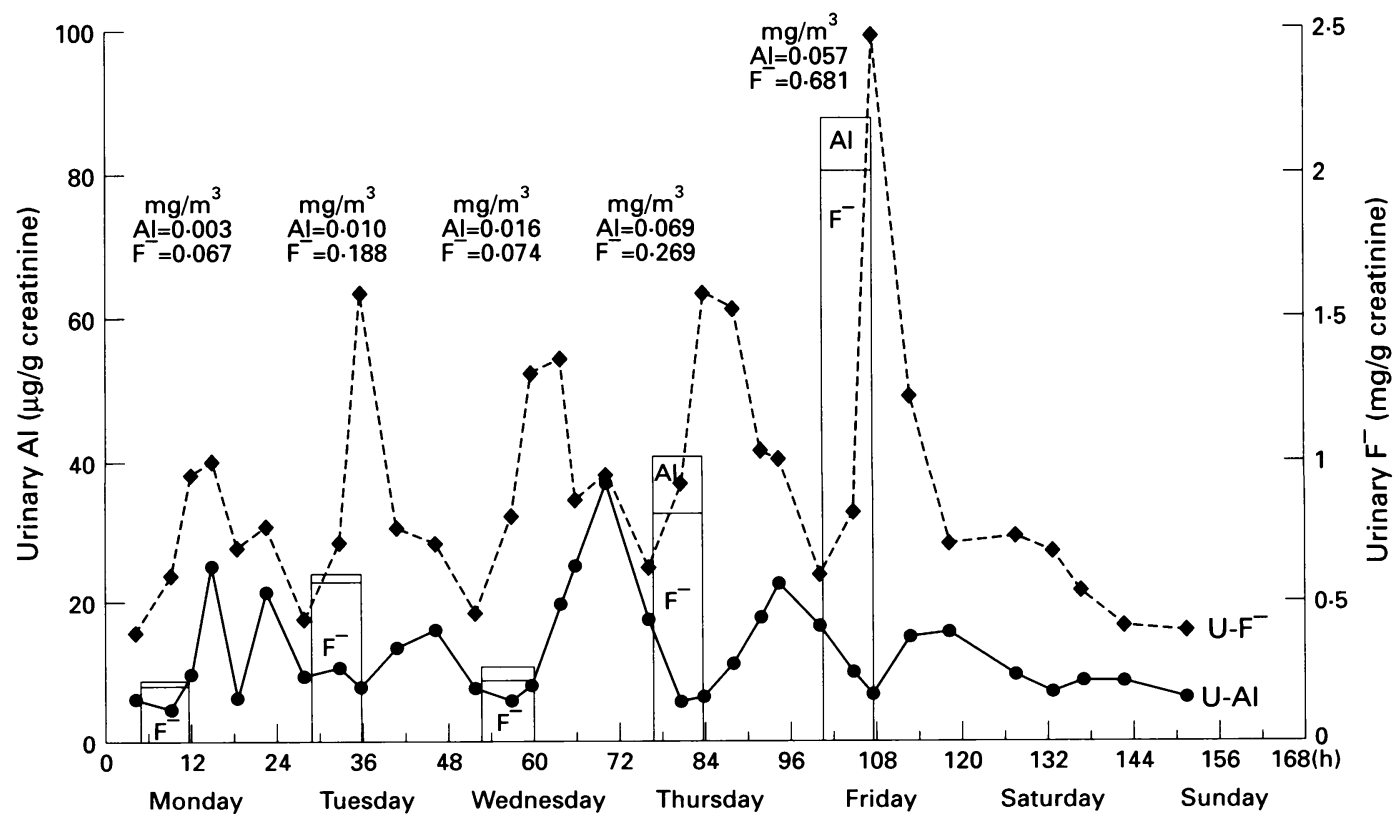



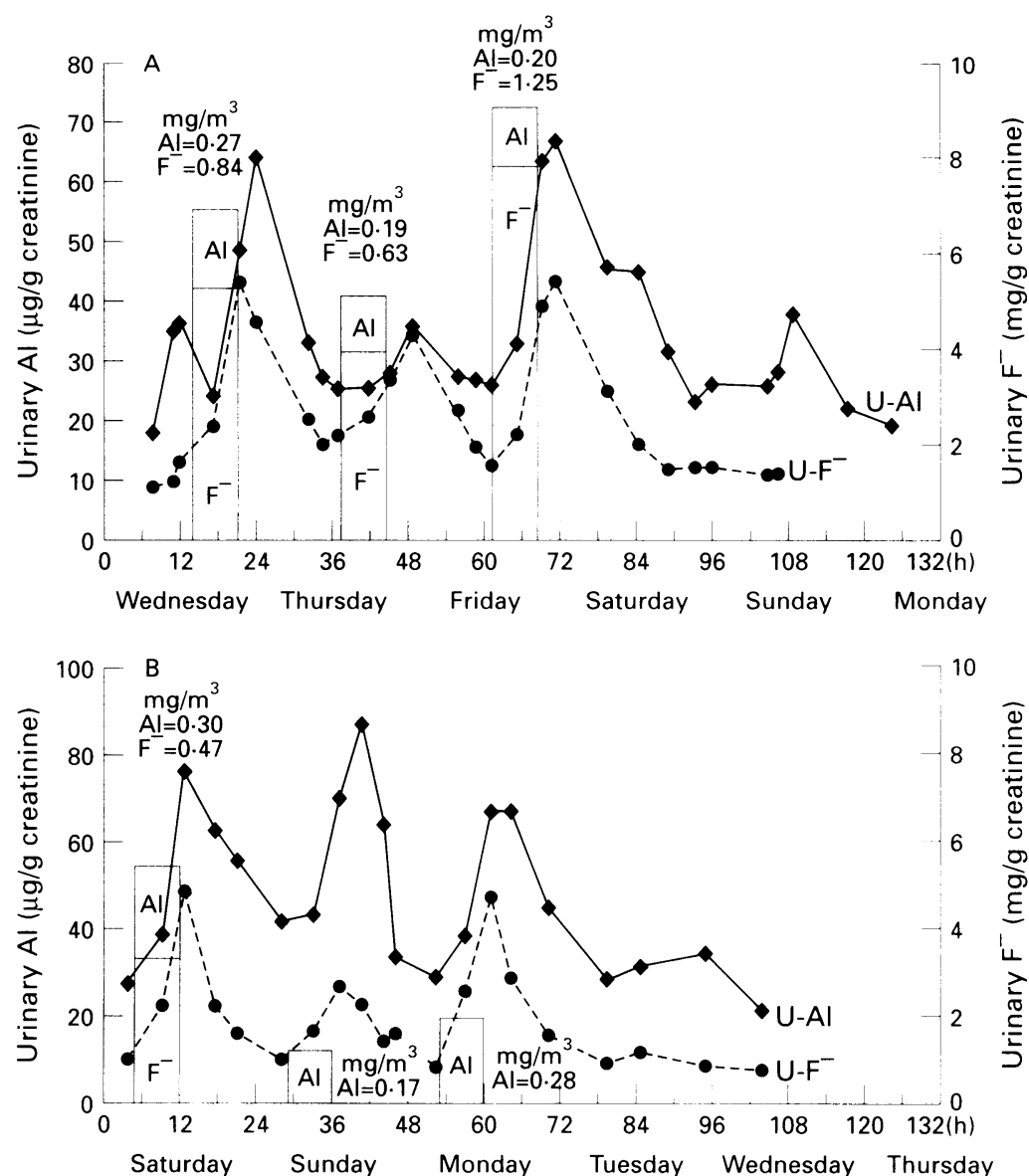

Figure 3 Atmospheric and urinary $A$ l and $F$ concentrations in potroom workers (plant $B$ enclosed potlines). (A) worker $B_{l},(B)$ worker $B_{2}$. Air concentrations of $A l$ and $F$ correspond to the soluble part. No atmospheric $F$ data on Sunday and Monday were available.
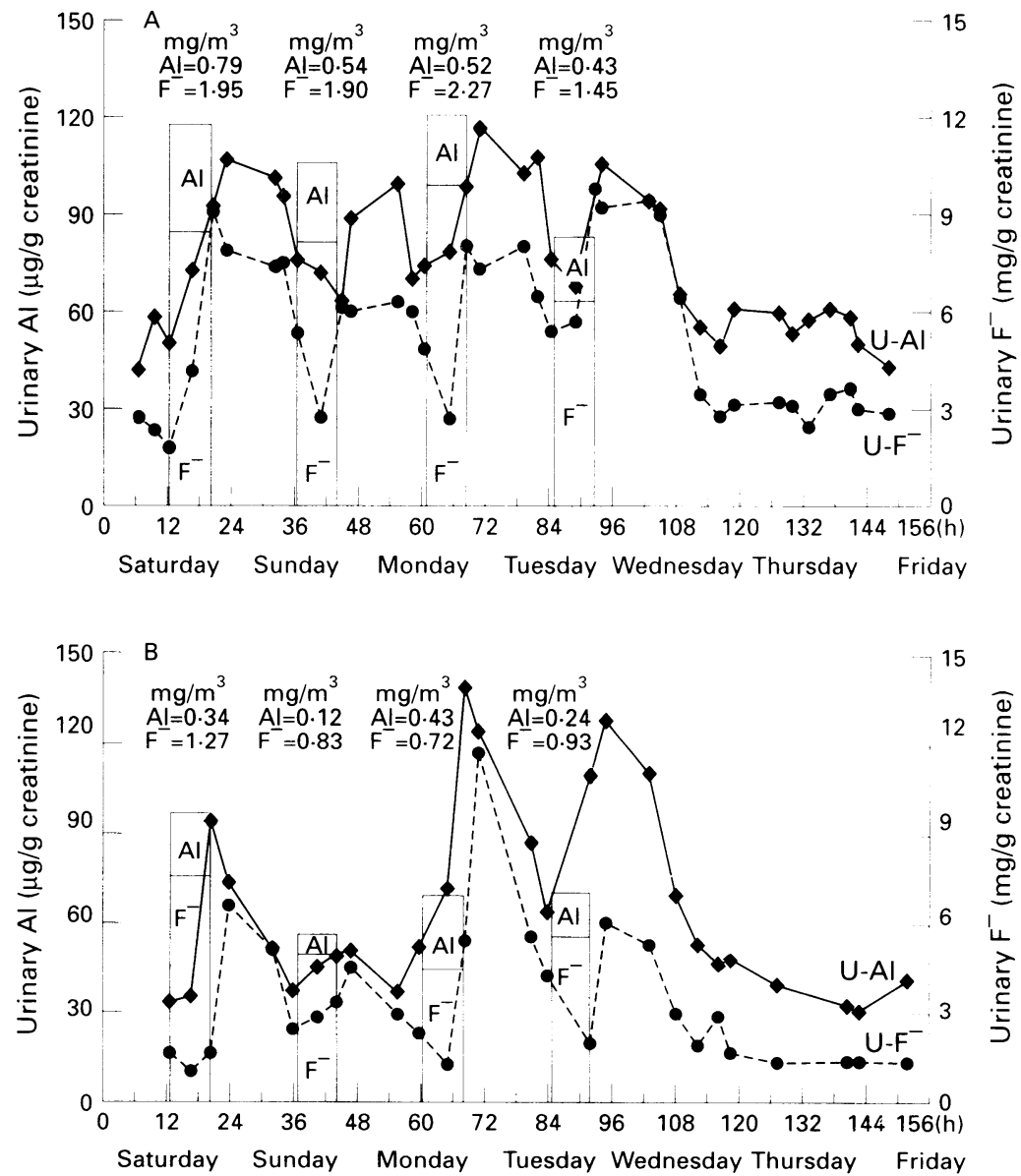

Figure 4 Atmospheric and urinary $A$ l and $F$ concentrations in potroom workers (plant $C$ open potlines). (A) worker $C_{l},(B)$ worker $C_{.}$. Air concentrations of $A l$ and $F$ correspond to the soluble part. two peaks. We found that the second peaks of both $\mathrm{Al}$ and $\mathrm{F}^{-}$occurred at a sampling time after the end of exposure as in the case of exposure to $\mathrm{AlF}_{3}$ (fig 1). The positions of the first daily $\mathrm{Al}$ and $\mathrm{F}$ peaks (fig 4 ) were similar to those of $\mathrm{F}$ and $\mathrm{Al}$ for potroom exposure in the aluminium production plant $\mathrm{B}$ (fig 3 ).

Technological differences existed between plants $B$ and $C$. In plant $B$, the important air pollutants were collected from enclosed potlines, and the atmospheric concentrations of $\mathrm{AlF}_{3}$ and $\mathrm{Al}_{2} \mathrm{O}_{3}$, which were fed automatically into the cell bath, were not very high. Enclosed potlines and automatic feeding could account for the discrepancies in the air pollutants and in their biological behaviour between the subjects in plants B and C. An example of this type of biologically different response was found between workers $C_{1}$ and $\mathrm{C}_{2}$ (fig 4). Worker $\mathrm{C}_{2}$ 's job was performed in the potroom, but he was less exposed to dust because he did not do exactly the same task as $\mathrm{C}_{1}$. Worker $\mathrm{C}_{1}$ often restored the surface of the electrolytic bath for a series of potlines by sweeping away the bath powder found on the floor around the cells. This operation was more dusty. The curves for $\mathrm{Al}$ and $\mathrm{F}$ for worker $\mathrm{C}_{2}$ (fig 4) showed a main daily peak for both elements; only a slight, but systematic deformation in the decreasing slopes marked the position of the second peak. This curve could be considered as intermediate between those of $\mathrm{B}_{1}, \mathrm{~B}_{2}$ (fig 3), and $\mathrm{C}_{1}$ (fig 4). The exposure was more uniform in plant $B$ that had the new potroom technology because the tasks were less diverse.

In several cases (figs 1, 2, 3, and 4) we noted a supplementary peak of $\mathrm{Al}$ excretion during the day after the last exposure. This $\mathrm{Al}$ peak in the rest day existed in all exposed subjects followed up in plant B. No equivalent tendency was found for $\mathrm{F}$ excretion in the same cases.

Finally, in this study we noted some specific characteristics in the peaks of the urinary excretion of $\mathrm{Al}$ and $\mathrm{F}$ attributable to different exposures: for exposure to $\mathrm{AlF}_{3}\left(\mathrm{~A}_{1}\right.$, fig 1 ): one delayed $\mathrm{Al}$ peak (delay $\simeq 8$ hours) associated with one delayed $F$ peak. For exposure to $\mathrm{HF}+\mathrm{AlF}_{\text {; }}\left(\mathrm{A}_{2}\right.$, fig 2): one isolated fast $\mathrm{F}$ peak and one delayed $\mathrm{Al}$ peak synchronised with one delayed $F$ peak (delay $\simeq 10$ or 11 hours). For exposure to $\mathrm{Al}$ and $\mathrm{F}^{-}$in potroom plant $B$ (nine workers, $B_{1}$ and $B_{2}$, fig 3 ): one fast $\mathrm{Al}$ peak associated with one fast $\mathrm{F}$ peak. For exposure to $\mathrm{Al}$ and $\mathrm{F}$ in potroom plant $\mathrm{C}$ (five workers, $\mathrm{C}_{1}$ and $\mathrm{C}_{2}$, fig 4): one fast $\mathrm{Al}$ peak associated with one fast $F$ peak and one delayed $\mathrm{Al}$ peak (delay 12/13 hours) associated with one delayed $F$ peak (delay $\simeq 10$ hours).

HALF LIFE

The mean (range) half life of $\mathrm{Al}$ in urinary excretion ( $\mathrm{n}=7$ ) was $7 \cdot 5(5-9)$ hours. For $\mathrm{F}$ $(\mathrm{n}=8)$ the mean (range) value was about 9 (6.5-13.5) hours. For subjects $C_{2}$ and $C_{4}$, a second $\mathrm{F}$ half life could be identified at 18 and 15 hours.

RELATION TO EXPOSURE

The atmospheric concentrations of $\mathrm{Al}$ are 
Table 1 Eight hour TWA concentrations of $A l$ and $F^{-}$in air during the survey and quantities excreted during several days of exposure by workers of plants $A, B$, and $C$

\begin{tabular}{|c|c|c|c|c|c|c|c|c|c|c|c|c|}
\hline Worker & $\begin{array}{l}\text { Days } \\
(n)\end{array}$ & $\begin{array}{l}\text { Soluble } \\
A l \\
\left(\mathrm{mg} / \mathrm{m}^{3}\right)\end{array}$ & $\begin{array}{l}\text { Insoluble } \\
\text { Al } \\
\left(\mathrm{mg} / \mathrm{m}^{3}\right)\end{array}$ & $\begin{array}{l}\text { Total } \\
\text { urinary* } \\
\text { Al } \\
(\mu g)\end{array}$ & $\begin{array}{l}\text { Daily mean } \\
\text { Al } \\
(\mu g)\end{array}$ & $\begin{array}{l}\text { Gaseous } \\
\text { soluble F- } \\
\left(\mathrm{mg} / \mathrm{m}^{3}\right)\end{array}$ & $\begin{array}{l}\text { Particulate } \\
\text { soluble } F^{-} \\
\left(\mathrm{mg} / \mathrm{m}^{3}\right)\end{array}$ & $\begin{array}{l}\text { Total } \\
\text { soluble } F^{-} \\
\left(\mathrm{mg} / \mathrm{m}^{3}\right)\end{array}$ & $\begin{array}{l}\text { Total } \\
\text { urinary } \\
F^{-} \\
(m g)\end{array}$ & $\begin{array}{l}\text { Daily mean } \\
F^{-} \\
(m g)\end{array}$ & $\begin{array}{l}\text { Molecular } \\
\text { ratio F-|Al } \\
\text { (soluble } \\
\text { part) air }\end{array}$ & $\begin{array}{l}\text { Molecular } \\
\text { ratio } F^{-} / A l \\
\text { urine }\end{array}$ \\
\hline $\begin{array}{l}A_{1} \\
A_{2} \\
B_{1} \\
B_{2} \\
B_{3} \\
B_{4} \\
B_{5} \\
B_{6} \\
B_{7} \\
B_{8} \\
B_{9} \\
C_{1} \\
C_{2} \\
C_{3} \\
C_{4} \\
C_{5}\end{array}$ & $\begin{array}{l}5 \\
5 \\
3 \\
3 \\
3 \\
3 \\
3 \\
3 \\
3 \\
3 \\
3 \\
4 \\
4 \\
4 \\
4 \\
4\end{array}$ & $\begin{array}{l}0.29 \\
0.03 \\
0.22 \\
0.25 \\
0 \cdot 15 \\
0 \cdot 20 \\
0 \cdot 18 \\
0 \cdot 14 \\
0.23 \\
0 \cdot 16 \\
0 \cdot 18 \\
0.56 \\
0.31 \\
0 \cdot 11 \\
0.21 \\
0.22\end{array}$ & $\begin{array}{l}4.79 \\
0.33 \\
0.35 \\
0.53 \\
0.29 \\
0.41 \\
0.29 \\
0.32 \\
0.62 \\
0.40 \\
0.33 \\
0.76 \\
0.10 \\
0.19 \\
0.32\end{array}$ & $\begin{array}{r}180 \\
99 \\
210 \\
257 \\
104 \\
180 \\
165 \\
176 \\
224 \\
110 \\
165 \\
393 \\
473 \\
321 \\
130 \\
312\end{array}$ & $\begin{array}{r}36 \\
20 \\
70 \\
86 \\
35 \\
60 \\
55 \\
59 \\
75 \\
37 \\
55 \\
98 \\
118 \\
80 \\
32 \\
78\end{array}$ & $\begin{array}{l}0.08 \\
0.25 \\
0.36 \\
\overline{0.14} \\
0.28 \\
0.41 \\
0.12 \\
- \\
- \\
- \\
0.98 \\
0.58 \\
0.53 \\
0.76 \\
0.76\end{array}$ & $\begin{array}{l}<0.1 \\
<0.1 \\
0.54 \\
- \\
0.44 \\
0.52 \\
0.82 \\
0.44 \\
- \\
- \\
- \\
0.91 \\
0.43 \\
0.26 \\
0.46 \\
0.65\end{array}$ & $\begin{array}{l}0.08 \\
0.25 \\
0.90 \\
- \\
0.58 \\
0.80 \\
1.23 \\
0.56 \\
- \\
- \\
- \\
1.89 \\
1.01 \\
0.79 \\
1.22 \\
1.41\end{array}$ & $\begin{array}{r}10 \cdot 2 \\
7 \cdot 3 \\
17 \cdot 3 \\
10 \cdot 6 \\
4 \cdot 8 \\
10 \cdot 3 \\
7 \\
9 \cdot 4 \\
12 \cdot 7 \\
6 \cdot 2 \\
15 \cdot 9 \\
27 \cdot 3 \\
24 \cdot 6 \\
7 \cdot 7 \\
5 \cdot 5 \\
10 \cdot 9\end{array}$ & $\begin{array}{l}2.0 \\
1.5 \\
5 \cdot 8 \\
3.5 \\
1.6 \\
3.4 \\
2.3 \\
3 \cdot 1 \\
4 \cdot 2 \\
2 \cdot 1 \\
5.3 \\
6.8 \\
6.1 \\
1.9 \\
1.4 \\
2.7\end{array}$ & $\begin{array}{c}0.4 \\
11.8 \\
5 \cdot 8 \\
-7 \cdot 5 \\
5 \cdot 7 \\
9 \cdot 7 \\
5 \cdot 7 \\
- \\
- \\
- \\
4 \cdot 8 \\
4.6 \\
10 \cdot 2 \\
8 \cdot 2 \\
9.1\end{array}$ & $\begin{array}{r}80 \cdot 6 \\
105.8 \\
116.7 \\
58.6 \\
64.9 \\
81.9 \\
60 \cdot 7 \\
76.6 \\
80.5 \\
80.8 \\
137.0 \\
98.3 \\
73.9 \\
34.3 \\
60.2 \\
49.9\end{array}$ \\
\hline
\end{tabular}

*Amount excreted in urine over $\mathrm{n}$ days.

reported in terms of insoluble and soluble $\mathrm{Al}$. Likewise, $\mathrm{F}^{-}$was evaluated as soluble gaseous $\mathrm{F}^{-}$, soluble particulate $\mathrm{F}^{-}$, and total soluble $\mathrm{F}^{-}$(table 1). The quantities of urinary $\mathrm{Al}$ and $\mathrm{F}^{-}$excreted each day of the survey were calculated for each subject. These daily amounts varied regularly around a mean value for each worker. These 16 workers excreted in their urine between 20 and $118 \mu \mathrm{g}$ of $\mathrm{Al}$ and between 1.4 and $6.8 \mathrm{mg}$ of $\mathrm{F}^{-}$during each working day. The individual molecular ratios of $\mathrm{F}^{-} / \mathrm{Al}$ ranged between 34 and 137 (10 values in the 58-82 range). In comparison the same molecular ratio in air (table 1 ), ranged from 4.6 to 11.8 (with the exception of the value of 0.4 for subject $A_{1}$, exposed only to $\mathrm{AlF}_{3}$ ). Excretion of $\mathrm{F}^{-}$exceeded $\mathrm{Al}$ excretion by an average factor of 80 , compared with the mean ratio of between seven and eight for soluble $\mathrm{Al}$ and $\mathrm{F}^{-}$in air. The relation between urinary $\mathrm{F}^{-}$and $\mathrm{Al}$ was calculated on a molecular basis from all the individual daily amounts excreted. This showed a significant correlation between them $(r=0.776, \mathrm{n}=67, \mathrm{P}<$ 0.0001 ). Assuming a linear relation, $5 \mu \mathrm{mol}$ of Al eliminated corresponded to $346 \mu \mathrm{mol}$ of $\mathrm{F}^{-}(\mathrm{Y}=67 \cdot 6 \mathrm{X}+7 \cdot 8)$.

Three relations between the exposure and the urinary excretion in electrolytic plants $B$ and $\mathrm{C}$ were examined for $\mathrm{Al}$ and for $\mathrm{F}^{-}$with individual daily data (time weighted averages (TWA) soluble concentration of $\mathrm{Al}$ and $\mathrm{F}^{-}$for atmospheric and urinary data).

The first relation between urinary $\mathrm{Al}$ concentration at the end of the daily work period and the airborne soluble $\mathrm{Al}$ concentration was calculated with a linear regression model as follows:

$$
\begin{gathered}
\mathrm{Y} 1=0 \cdot 127 \mathrm{X}+27 \cdot 1 \\
(r=0.411 ; \mathrm{df}=15 ; \mathrm{P}<0.005)
\end{gathered}
$$

where $\mathrm{Y} 1$ is the urinary concentration of $\mathrm{Al}$ at the end of the shift (units $\mu \mathrm{g} / \mathrm{g}$ creatinine) and $\mathrm{X}$ is the atmospheric concentration of soluble Al (units: $\mu \mathrm{g} / \mathrm{m}^{3}$ ). An atmospheric $\mathrm{Al}$ concentration of $500 \mu \mathrm{g} / \mathrm{m}^{3}$ corresponds to a urinary excretion of $90 \mu \mathrm{g} / \mathrm{g}$ creatinine.

The second relation corresponded to the regression model:

$$
\begin{gathered}
\mathrm{Y} 2=0.153 \mathrm{X}+27 \cdot 8 \\
(r=0.464 ; \mathrm{df}=43 ; \mathrm{P}<0.0015)
\end{gathered}
$$

where $\mathrm{Y} 2$ is the peak concentration of $\mathrm{Al}$ in urine. With this model, the same atmospheric Al concentration of $500 \mu \mathrm{g} / \mathrm{m}^{3}$ corresponded to a urinary excretion of $105 \mu \mathrm{g} / \mathrm{g}$ creatinine.

The third relation between exposure and concentrations excreted in urine during 24 hours was also calculated:

$$
\begin{gathered}
\mathrm{Y} 3=0.615 \mathrm{X}+28 \\
(r=0.649 ; \mathrm{df}=15 ; \mathrm{P}<0.006)
\end{gathered}
$$

where $\mathrm{Y} 3$ is the amount of $\mathrm{Al}$ excreted a day. The same atmospheric Al TWA of $500 \mu \mathrm{g} / \mathrm{m}^{3}$ corresponded to $110.5 \mu \mathrm{g} \mathrm{Al}$ excreted a day.

For $\mathrm{F}^{-}$, the regression models are expressed in the same way as for aluminium:

$$
\begin{gathered}
\mathrm{Y} 4=2.24 \mathrm{X} 2+0.77 \text { for urinary } \mathrm{F}^{-} \text {(end of } \\
\text { shift) }(r=0.490 ; \mathrm{df}=29 ; \mathrm{P}<0.006) \\
\mathrm{Y} 5=2.27 \mathrm{X} 2+1.72
\end{gathered}
$$

for urinary $\mathrm{F}^{-}$(peak) $(r=0.412 ; \mathrm{df}=29 ; \mathrm{P}<$ 0.02 ) where $X 2$ is the soluble atmospheric concentration in $\mathrm{mg} / \mathrm{m}^{3}$ and $\mathrm{Y} 3$ and $\mathrm{Y} 4$ are the urinary $\mathrm{F}^{-}$concentration $(\mathrm{mg} / \mathrm{g}$ creatinine) for the end of the shift and the peak values, respectively. At the end of shift, urinary $\mathrm{F}^{-}$reached $6.4 \mathrm{mg} / \mathrm{g}$ creatinine for $2.5 \mathrm{mg} / \mathrm{m}^{3}$ of atmospheric $\mathrm{F}^{-}$. In the second situation, the peak value reached $7.4 \mathrm{mg} / \mathrm{g}$ creatinine.

For the net amounts of $\mathrm{F}^{-}$, the model was:

$$
\begin{gathered}
\mathrm{Y} 6=2.5 \mathrm{X} 2+1 \cdot 12 \\
(r=0.586 ; \mathrm{df}=11 ; \mathrm{P}<0.04) .
\end{gathered}
$$

With this relation, the amount of $\mathrm{F}^{-}$excreted a day, Y6, after exposure to $2.5 \mathrm{mg} / \mathrm{m}^{3}$ of atmospheric $\mathrm{F}^{-}$during one shift was estimated to be $7.4 \mathrm{mg}$ of $\mathrm{F}^{-}$.

\section{Discussion}

Our study shows some characteristics of the urinary excretion of $\mathrm{Al}$ and $\mathrm{F}^{-}$related to the compounds of exposure. We have shown the individual curves to illustrate the characteristics of the urinary excretion. One could argue that generalisations cannot be made from individual curves but several interesting points 
emerge: some cases of simple and combined exposure were studied with good urinary responses from the 418 samples collected from the 16 subjects; they clearly showed a coherent and homogeneous urinary pattern for both elements between days for a given subject and between subjects in the same working conditions. Both of these points underline the representativeness of the observed data.

The results provide a better understanding of the kinetics of excretion of $\mathrm{Al}$ and $\mathrm{F}^{-}$. From these kinetic properties we noted that:

(1) simultaneous associated peaks of $\mathrm{Al}$ and $\mathrm{F}^{-}$when these elements were found together in the compound of exposure $\left(\mathrm{AlF}_{3}\right)$.

(2) Specific time of excretion of the element for a specific compound of exposure. For Al $\mathrm{F}_{3}$ this corresponded to one delayed peak after the end of the shift.

(3) A two step excretion of one element when exposure was to two different compounds $\left(\mathrm{F}^{-}\right.$ in $\mathrm{AlF}_{3}$ and $\mathrm{HF}$ ).

(4) The change in the molecular ratio between $\mathrm{F}^{-}$and $\mathrm{Al}$ in air (soluble part) and in urine.

Some biological limit values, such as the United States biological exposure indices (BEI) from the American Conference of Governmental Industrial Hygienists (ACGIH), ${ }^{31}$ are established based on the principle that they are equivalent to atmospheric limit values. We have therefore developed several relations with different biological values corresponding to the atmospheric limit values, each of which can be justified. It seems that the most effective of these is the relation between the atmospheric concentration and the quantities excreted daily in the urine. In practice, however, it is not easy to collect daily urine samples in occupational medicine.

Table 2 shows the comparison of our results $\left(\mathrm{F}^{-}\right)$with the data of BEIs ${ }^{31}$ and Biologische Arbeitstofftoleranzwerte (BAT) ${ }^{32}$ for the urine samples at the end of a shift with a TWA exposure to $\mathrm{F}^{-}$of $2.5 \mathrm{mg} / \mathrm{m}^{3}$

In a study dealing with workers exposed essentially to $\mathrm{HF}$, Högstedt ${ }^{33}$ found a relation between exposure and $\mathrm{F}^{-}$in samples of urine after a shift $(Y=1.4+4.6 \mathrm{X})$, and between exposure and total $\mathrm{F}^{-}$excretion in 24 hour urine samples $(Y=0.6+3 \cdot 2 \mathrm{X})$. With one exposure to $2.5 \mathrm{mg} / \mathrm{m}^{3}$ of $\mathrm{F}^{-}$, the equivalent urinary values were $12.9 \mathrm{mg} / \mathrm{l}$ (after the shift) and $8.6 \mathrm{mg} / 24$ hours (daily excretion). The differences between our and Högstedt's results after a shift may be due to the difference in exposures - that is, essentially limited to HF in Högstedt's case and consisting of a mixture of compounds in our situation.

Table $2 F^{-}$: biological values corresponding to an exposure of $2.5 \mathrm{mg} / \mathrm{m}^{3}$

\begin{tabular}{lllllll}
\hline & $\begin{array}{l}\text { BEI } \\
\text { end of shift }\end{array}$ & $\begin{array}{l}\text { BAT } \\
\text { end of shift }\end{array}$ & $\begin{array}{l}\text { Our results } \\
\text { shift }\end{array}$ & Peak & $\begin{array}{l}\text { Daily amount } \\
\text { mg/day }\end{array}$ \\
\hline $\begin{array}{l}\text { Urinary fluoride } \\
\text { (mg/g creatinine) }\end{array}$ & 10 & 7 & 6.4 & $7 \cdot 4$ & $7 \cdot 4$ \\
\hline
\end{tabular}

In contrast, our results do not differ significantly from those of Steinegger and Schlatter, which were also obtained in $\mathrm{Al}$ smelters. ${ }^{18}$ They found a good relation between $7 \mathrm{mg} / 1$ of $\mathrm{F}^{-}$in urine and an exposure to $2.5 \mathrm{mg} / \mathrm{m}^{3}$ of $\mathrm{F}^{-}(\mathrm{Y}=1.08 \mathrm{X}+2.31)$. We found a similar correlation with our data from samples from the end of a shift and the daily quantities. These conclusions only concern the exposures in aluminium smelting plants.

The $\mathrm{F}^{-}$half life of nine hours, calculated here from urinary excretion rates, can be compared with Ekstrand and Ehrnebo's value of $5 \cdot 1$ hours..$^{22}$ In that study the pharmacokinetic data were obtained from volunteers after an intake of $10 \mathrm{mg}$ of $\mathrm{Na} \mathrm{F}$.

For $\mathrm{Al}$, the BAT value is $200 \mu \mathrm{g} / 1$ in urine at the end of a shift. ${ }^{32}$ Sjögren et al ${ }^{13}$ found a relation between the urinary concentration after a shift and the corresponding air concentration of $\mathrm{Al}$ :

urinary $\mathrm{Al}(\mu \mathrm{g} / \mathrm{l})=34.7 \times \operatorname{air} \mathrm{Al}\left(\mathrm{mg} / \mathrm{m}^{3}\right)+24.5$

Mussi found a similar equation ${ }^{34}$ :

urinary $\mathrm{Al}(\mu \mathrm{g} / \mathrm{l})=36 \times \operatorname{air} \mathrm{Al}\left(\mathrm{mg} / \mathrm{m}^{3}\right)-16$.

In these two studies the exposed workers were $\mathrm{Al}$ welders.

With our model the corresponding exposure value for excretion of $200 \mu \mathrm{g} / \mathrm{g}$ creatinine after a shift is $1.36 \mathrm{mg} / \mathrm{m}^{3}$ (near to the BAT value). If we consider the quantities excreted in place of concentrations, amounts of $200 \mu \mathrm{g}$ and $400 \mu \mathrm{g}$ of $\mathrm{Al}$ eliminated daily correspond to exposures of $0.280 \mathrm{mg} / \mathrm{m}^{3}$ and 0.600 $\mathrm{mg} / \mathrm{m}^{3}$ of soluble $\mathrm{Al}$, respectively.

The Al elimination half life in our study was calculated to be about $7 \cdot 5$ hours, a value equivalent to that of Sjögren $e t$ al, who found it to be eight hours. The calculation of these half lives in our volunteers was accurate, with slight variations between subjects.

These results pointed out the existence of significant differences in the behaviour of a xenobiotic in urine depending on its original molecular form during exposure. The typical example in this study was that of a worker exposed to $\mathrm{AlF}_{3}\left(\mathrm{~A}_{1}\right)$. The $\mathrm{Al}$ and $\mathrm{F}^{-}$curves (fig 1) show their maxima several hours after the end of the shift, for $\mathrm{Al}$ the end of the shift corresponded to the minimum excretion. Consequently, the end of the shift seems to be an unsuitable time to take samples in practice. This is highly important in occupational hygiene as it has a direct bearing on the setting of a limit value, depending upon the monitoring strategy.

An important characteristic taken into account in the development of a sampling strategy is the elimination half life, and the classic approach in the determination of a biological limit value is the statistical validation of a relation between exposure concentrations and the concentrations at the end of the shift. This is an unsatisfactory method when a delay exists in the urinary excretion of the substance, and this discrepancy is reinforced in the case of double peaks as shown here. For 
example, in the plant $\mathrm{C}$, where broad urinary peaks were found (fig 4), the concentrations of $\mathrm{F}^{-}$and $\mathrm{Al}$ showed two peaks or one large peak that led to a higher concentration at the beginning of the next day than was found with a single peak. A second consequence of this delay is a cumulative effect due to the lack of time between exposure periods for sufficient elimination. This has the same effect as a longer half life. This also leads to a modified relation between the excretion (measured as concentration) and the exposure concentration.

We thank Dr J P Coulon, G Lafitte-Rigaud, F Barbier, and B Buclez occupational physicians for their participation in the field study, and Mrs C Sellier and C Guillemin for their technical assistance.

1 Alfrey AC, Le Gendre GR, Kaehny WD. The dialysis encephalopathy syndrome, possible aluminium intoxication. N Engl $₹$ Med 1976;294:184-8.

2 Masselot JP, Adhemar JP, Jaudon MC, Kleinknect D, Galli A. Reversible dialysis encephalopathy: role for aluminum-containing gels. Lancet 1978;ii:1386-7.

3 Poisson M, Mashaly R, Lebkiri B. Dialysis encephalopathy: recovery after interruption of aluminum intake. $B M F 1978 ; 2: 1610-1$

4 Lione A. Aluminum toxicology and the aluminumcontaining medications. Pharm Ther 1985;29:255-85.

5 Gaffuri E, Donna A, Pietra R, Sabbioni E. Pulmonary changes and aluminum levels following inhalation of alumina dust: a study on four exposed workers. Med Lav 1985;76:222-7.

6 Gilks B, Churg A. Aluminum-induced pulmonary fibrosis: do fibers play a role? Am Rev Respir Dis 1987;136:176-9.

7 Dinman Bertram D. Alumina-related pulmonary disease. f Occup Med 1988;30:328-35.

8 Soyseth V, Kongerud J. Prevalence of respiratory disorders among aluminium potroom workers in relation to exposure to fluoride. $B r \mathcal{F}$ Ind Med 1992;49:125-30.

9 Longstreth WT, Rosenstock L, Heyer NJ. Neurologic disorder in three aluminum smelter workers. Arch Inter Med 1985;145:1972-5.

10 Hosovski E, Mastelica Z, Sunderic D, Radulovic D. Mental abilities of workers exposed to aluminium. Med Lav 1990;81:119-23.

11 Sjögren B, Lundberg I, Lidums V. Aluminium in the blood and urine of industrially exposed workers. Br f Ind Med 1983;40:301-4.

12 Sjögren $B$, Lidums V, Häkansson $M$, Hedström $L$. Exposure and urinary excretion of aluminum durin welding. Scand f Work Environ Health 1985;11:39-43.

13 Sjögren B, Elinder CG, Lidums V, Chang G. Uptake and urinary excretion of aluminum among welders. Int Arch Occup Environ Health 1988;60:77-9.
14 Ljunggren KG, Lidums V, Sjögren B. Blood and urine concentrations of aluminium among workers exposed to aluminium flake powders. Br $\mathcal{F}$ Ind Med 1991;48:106-9.

15 Elinder CG, Ahrengart L, Lidums V, Petterson E, Sjögren B. Evidence of aluminium accumulation in aluminium welders. Br F Ind Med 1991;48:735-8.

16 Schlatter C, Steinegger A, Rickenbacher U, Hans C, Lengey A. Aluminiumspiegel im Blutplasma bei Arbeitern in der Aluminium-Industrie. Médecine Sociale Arbeitern in der Aluminium-

17 Röllin HB, Theodorou P, Kilroe-Smith TA. The effect of exposure to aluminium on concentrations of essential exposure to aluminium on concentrations of essential metals in serum

18 Steinegger AF, Schlatter C. Evaluation of fluoride exposure in aluminium smelters: state of the art. Med Lav 1992;83:489-98.

19 Dinman BD, Bovard WJ, Bonney TB, Cohen JM, Colwell MO. Excretion of fluorides during a seven-day workweek-Part 2. F Occup Med 1976;18:14-6.

20 Horiuchi T, Nasu I, Morimoto M. Circadian rhythm of urinary fluoride excretion in a human adult consuming space food. 13th Conference of the international society for fluoride research, Nov. 14-17, 1983; New-Delhi, India. Fluoride 1984;17:173-7.

21 Zober A, Geldmacher M, Mallinekrodt V, Schaller KH Renal fluoride excretion as a useful parameter for monitoring hydrofluoric acid-exposed persons. Int Arch Occup Environ Health 1977;40:13-24.

22 Eckstrand J, Ehrnebo M. The relationship between plasma fluoride, urinary excretion rate and urine fluoride concentration in man. $\mathcal{F}$ Occup Med 1983;25:745-8.

23 Cuturkova R. Kinetika na eliminirane na fluor pri eksponirani rabotnici. Problemi na higienata 1984;9:73-8.

24 Granjean P, Horder M, Thomassen Y. Fluoride, aluminum and phosphate kinetics in cryolite workers. minum accup Med 1990;32:58-63.

25 Ehrnebo M, Ekstrand J. Occupational fluoride exposure and plasma fluoride levels in man. Int Arch Occup and plasma fluoride levels in

26 Demange $M$. Méthodes de mise en solution des poussières prélevées en vue de leur analyse. Vandoeuvres Cedex, France: INRS, 1988. (Document de Travail No 297.047/MD.)

27 Demange $M$, Gendre JC, Hervé-Bazin B, Carton B, Peltier A. Aerosol evaluation difficulties due to particle deposition on filter holder inner walls. Ann Occup Hyg 1990;34:399-403.

28 Oster $\mathrm{O}$. The aluminium content of human serum determined by atomic absorption spectroscopy with a mined by atomic absorption spectroscopy with

29 Tusl J. Direct determination of fluoride in human urine using fluoride electrode. Clin Chim Acta 1970;27: 219-23.

30 Labaune JP. Pharmacocinétique, principes fondamentaux. Paris: Masson 1984:221.

31 American Conference of Governmental Industrial Hygienists. Threshold limit values for chemical substances and physical agents and biological exposure indices. Cincinnati: ACGIH 1993-1994.

32 Deutsche Forschungsgemeinschaft. Maximum concentrations at the workplace and biological tolerance values for working material. Weinheim: DFG, 1992.

33 Högstedt C. Fluorides in biological monitoring and surveillance of workers exposed to chemicals. Washington: lance of workers exposed to chemicals. Washingto

34 Mussi I, Calzaferri G, Buratti M, Alesio L. Behaviour of plasma and urinary aluminium levels in occupationally exposed subjects. Int Arch Occup Environ Health 1984 54:155-61. 